\title{
The Effect of Split Squat Jump and Jump to Box Exercises Towards Athlete Front Kick Ability at Perguruan Silaturahmi Pencak Silat Padang
}

\author{
Z Johor \\ Faculty of Sports Science, Universitas Negeri Padang, Prof. Dr. Hamka Street, Padang, Indonesia \\ *Corresponding author. Email: zainuljohur@gmail.com

\begin{abstract}
The problem of this research is the low ability of the front kickers of Perguruan Silaturahmi Pencak Silat athletes in Padang. The purpose of this study was to determine the effect of Split Squat Jump and Jump To Box on enhancement the ability of the front kick of Pencak Silat athlete in Padang.This Study used experimental approach. The study was conducted at the Perguruan Silaturahmi Pencak Silat in Padang. The sample of this study were 20 athletes. In collecting the data, the researcher used pre-test and post-test. Pre-test was done before giving the treatment, and post-test was done after given treatment. The technique of data collection is used the front kick ability test and the data analyze by using t-test. This study can be concluded: 1. There is a significant effect of training method on the Split Squat Jump ability of the front kick of Perguruan Silaturahmi Pencak Silat athlete in Padang with tcount of 4.79 while ttable is 1.833 tcount $>$ ttable (4.79> 1.833). 2. There is a significant effect of training method on the Jump To Box ability of the front kick of Silaturahmi Pencak Silat athlete in Padang with tcount 7.73 while ttable 1.833 then tcount > ttable (4.79> 1.833). 3. Split Squat Jump exercise is better than Jump To Box exercise toward the ability of the front kick of the Pencak Silat athlete in Padang. With a mean score of 87.05> 81.95. It means that there is a difference enhancement of front kick by using Split Squat Jump and Jump To Box exercises.
\end{abstract}

Keywords: Split squat jump, jump to box exercises, front kick ability

\section{INTRODUCTION}

Achievement is one of the goals or targets to be achieved by sportsmen. To achieve a sporting achievement, efforts are needed as revealed in the Law of the Republic of Indonesia concerning the National Sports system No. 3 article 1 year 2005 item 7 which states that: "Sportsmen are players who attend regular training and championships with full dedication to achieving achievements". So, it can be understood that coaching and enhancing sports achievements require planning training that is mature, programmed, organized, and continuous, then followers of participation in championships.

There are many factors influence the achievement of optimal sports both internal and external factors. The internal factors are athletes' physical, technical, and mental abilities, while external factors are factors that arise from outside athletes such as coaches, infrastructure, family, climate, nutritious food and so on. Thus, to achieve good and maximum achievements must be supported by planned and maximum guidance.

One of the many branches of achievement sports is Pencak Silat. Pencak silat is an Indonesian martial art that is cultured from generation to generation until now and has always developed in quality and quantity. This can be seen by the large number of martial arts groups that have developed in Indonesia. One of them is Silaturahmi group Pencak Silat in Padang, which until now still exists and always raises new athletes.

In its heyday, Silaturahmi group Pencak Silat athletes often became a sports ambassador for the pencak silat branch both at regional and national levels. However, in the present, the achievements of Peguruan Silaturahmi Pencak Silat athletes are decreasing. There is almost no increase in each championship that is followed.

The success of a fighter in a match can be influenced by the quality of the physical condition, skills possessed, the use of techniques in competing and maturity in carrying out the technique. Basic techniques that need to be mastered and often used by a fighter in the competition include: horses, tide attitude, steps, defense techniques, attack and punch techniques, dropping techniques, and catching techniques. Which in the attack technique there is one kick technique, one of which is the front kick technique.

The front kick is an attack that uses one foot and leg, the trajectory is towards the front with the body facing forward, with the base of the fingers of the inner toes, with the target of the heart and chin. Johansyah 
Lubis (2014: 36). Front kicks are not easily anticipated by opponents, front kicks are carried out, must be done as quickly as possible. If not, the opponent will easily dodge or even catch the kick that we did. In order for the kick to be inevitable or captured by opponents, it takes the ability to do the kick. In order for the kick to be carried out quickly there are several things that influence it.

According to Mukholid (2005: 114). in making kicks its necessary:

Kicks with strength (power) and the speed and flexibility of the leg. 2. View and concentration in the direction of the intended target, so that the time is right. 3 . The movement does not only rely on the legs, but must be coordinated with the waist rotation. 4. Balance really must be maintained in such a way, because in doing a quick and powerful kick a good body balance is needed. 5 . The foot that is used to kick after making a kick, should immediately be pulled and returned to the ready position.

Based on the initial research, one of the factors that influence on the decline in achievement is the low quality of the ability to do a Front Kick. The front kick often gets anticipation from the opponent when competing. In improving the ability to do a good Front Kick, many correct training methods are needed. The training method that is widely used today is Plyometric exercises.

The Plyometric exercises is to train the ability of the front kick, athletes should choose the form of training needed Plyometric which contains elements of Jump, because Jump can cause contractions in the leg muscles. Based on these problems, an experimental study that is suitable for practicing Front Kick Capability is needed pencak silat athletes in Padang. A form of Plyometric exercise that is suitable for practicing the ability to do front kicks is the Split Squat Jump and Jump To Box.

The aims of this study is to see the effect of Pylometric exercises on the ability to do the front kick of Pencak Silat athletes in Padang. The Pylometric exercises examined in this study were the Split Squat Jump and Jump To Box. From the form of the Pylometric exercise, the researcher will see the effect on the ability to do the front kick of the Pencak Silat athletes in Padang.

Plyometric exercises are a form of exercise that can enhance the power explosive of lower limb muscles, especially the leg muscles, with a form of exercise such as bound, jump, and hop. Basically this type of exercise is carried out to produce and increase leg muscle power, so that it can provide a meaningful contribution to the sport that is being pursued.

Split Squat Jump is a part of plyometric exercises. Split Squat Jump training can increase the ability of leg muscle strength in carrying out a movement. Split
Squat Jump training can improve Front Kick Capability. Split Squat Jump exercise is a type of exercise that is very practical and has a very good effect on the results Capability Front kick.

Split Squat Jump exercise type is relatively simple that has a good effect on leg muscle strength in enhancing the ability of explosive power in athletes who perform such exercises. Muscle contractions that occur in this type of exercise are very high. This can be felt when doing split leg muscles stretched and then jumped up, when the landing of the foot is opened again with the shape of the front horses. The weight burden held by the muscles on the part of the foot when landing from the jump with the position opened with the shape of the front horses, will experience a strong contraction. Based on this explanation, it can be said that the Split Squat Jump exercise can sharpen the strength of all leg muscles.

\section{METHOD}

This study uses an experimental method (treatment) with a type of comparative research, namely Split Squat Jump and Jump To Box exercises as independent variables, and Straight Kick Ability as the dependent variable towards Perguruan Silaturahmi Pencak Silat athletes in Padang. The samples of this study were 20 athletes taken by using Purporsive Sampling sampling techniques. This study gave treatment to one group of Split Squat Jump and Jump To Box exercises. Before the treatment is given, an initial test was carried out to determine the experimental group, then the final test is given. This study used The one group Pre-test Post-Test Design. (Arikunto, 1989: 25). The following is the design of this study:

Table 1. Research Design

\begin{tabular}{|c|c|c|c|}
\hline Grup & Pre-Test & Treatment & Post-Test \\
\hline A & $\mathrm{X}_{1 \mathrm{~A}}$ & $\begin{array}{l}\text { Split Squat } \\
\text { Jump }\end{array}$ & $\mathrm{X}_{1 \mathrm{~B}}$ \\
\hline $\mathrm{B}$ & $X_{2 A}$ & Jump to box & $\mathrm{X}_{2 \mathrm{~B}}$ \\
\hline \multicolumn{4}{|c|}{ Description: } \\
\hline $\mathrm{X}_{1 \mathrm{~A}}$ & \multicolumn{3}{|c|}{ : Initial Test (Pre Test) Front Kick } \\
\hline $\mathrm{X}_{1 \mathrm{~B}}$ & \multicolumn{3}{|c|}{ : Final Test (Post Test) Front Kick after } \\
\hline \multicolumn{4}{|c|}{$16 \times$ the meeting was given training. } \\
\hline $\mathrm{X}_{1}$ & \multicolumn{3}{|c|}{ : Spilled Squat Jump training } \\
\hline $\mathrm{X}_{2 \mathrm{~A}}$ & \multicolumn{3}{|c|}{ : Preliminary Test (Pre Test) Front Kick } \\
\hline $\mathrm{Xp}_{2 \mathrm{~B}}$ & \multicolumn{3}{|c|}{ : Test (Post Test) Final Front Kick after } \\
\hline \multicolumn{4}{|c|}{$16 \times$ meetings given training } \\
\hline $\mathrm{X}_{2}$ & \multicolumn{3}{|c|}{ : Jump to box training } \\
\hline
\end{tabular}

Before given the treatment, the sample carries out the initial test of doing a Front Kick. After that the sample is treated according to what is explained. Treatment was given for 16 meetings for 4 weeks, with the volume of exercise 4 times a week. After given treatment, a final test (Post-Test) held is to see if there is any influence on the form of training. To get a Post- 
Test, an exercise program is needed to get the results of the Split Squat Jump exercise toward Front Kicks. Group division is based on initial ranking or ordinal maching pairing (Stisno (2004: 512) in Andrea (2011:) the implementation of group machining or division is as follows:

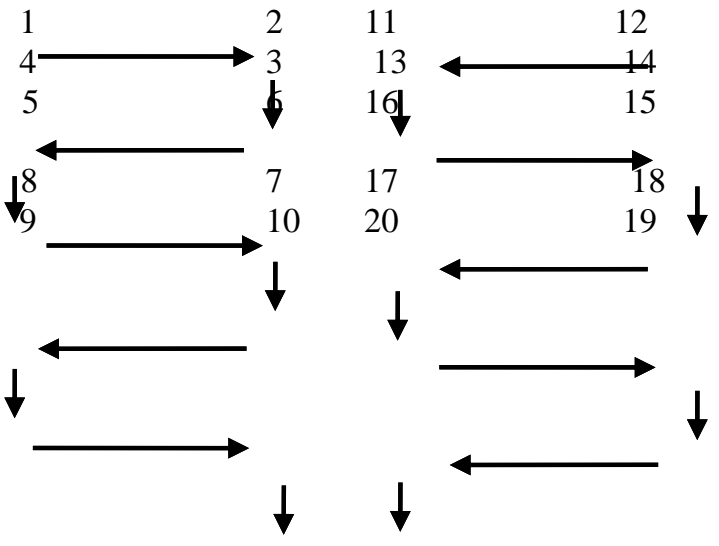

The instrument used in this study is the front kick ability test. The athletes get ready to stand behind the belt with a distance of $90 \mathrm{~cm}$, horizontally and $100 \mathrm{~cm}$ high. Then do a kick where the straight kick technique has to pass through the belt/ rope without touching it, every kick that touches the belt/rope will be reduced 1 . Each athlete kicks in a row with 10 right foot kicks and 10 left foot kicks. The implementation can be done 3 times and the highest score is taken. (Johansyah Lubis, 2014).

Tests and measurements were used for collecting the data. In this research, the researcher used several supporting tools, as follows: Test Forms, Stationery, Meters, Cameras and Samsak.

After all preparations have been made from the population and the determination of the sample, the experimental activity begins with:

1. Pre-Test with the aim of getting the highest data from the Front Kick

2. Sorting (ranked) highest value, Front Kick Capability what has been done and made a ranking.

3. First the sample conducts Trial and Error. Each exercise to get the maximum ability done in making an exercise program.

4. After the training program is ready to be made, the sample conducts exercises based on an exercise program for 4 weeks with a frequency of 4 times in a week, on Monday, Wednesday, Friday, and Sunday.

5. After the treatment is carried out, Post-Test is with the aim of obtaining the final highest value data from the Front Kick.

Data collected from the results of the Pre-Test and Post-Test will be processed using statistical analysis techniques to prove whether the hypothesis proposed in this study can be accepted or rejected. Before testing hypotheses, an analysis of the requirements test (t-test) (Sudjana 2002) is carried out with the following details:

1. Testing requirements analysis tests include:

2. Normality test data using the Liliefors

3. Homogeneity Test formula with the formula:

$$
F=\frac{\text { Varian terbesar }}{\text { Varian terkecil }}
$$

4. Hypothesis testing is used by the Comparative formula Dependent Sample

$$
t=\frac{\left(\overline{X_{1}}-\overline{X_{2}}\right)}{\sqrt{\frac{\sum D^{2}-\frac{\left(\sum D\right)^{2}}{n}}{n(n-1)}}}
$$

Description:

$$
\begin{array}{lll}
\overline{X_{1}}= & \text { Mean of first sample } \\
\overline{X_{2}}= & \text { Mean of second sample } \\
D & = & \text { Difference between sample scores } 1 \text { and } \\
2 & \\
D^{2}= & \text { Different sample scores raised } 2 \\
\sum D= & \text { Number of units of difference } \\
\sum D^{2}= & \text { er of units of difference raised 2 }
\end{array}
$$

$n=$ Number of samples

5. Comparison of $t_{\text {count }}$ with $t_{\text {table }}$ contained in the percentile value for $t$ distribution. If $t_{\text {count }}$ is greater than $t_{\text {table, }}$, the independent variable has an effect on the dependent variable. Conversely, if $t_{\text {count }}$ is smaller than $t_{\text {table }}$, the free variable does not give effect to the dependent variable.

\section{RESULT AND DISCUSSION}

From the data analyzed, the results were obtained that before the sample was given the treatment of the Split Squat Jump training method, the sample was carried out with the acquisition of a diverse score. In the initial ability test the score of 10 samples in the pretest with an average $=74.55$, Standard Deviation $=$ 4.82, Maxsimum value $=82.5$ and Minimum value $=$ 65 . While in the post test with an average $=87.05$, Standard Deviation $=6.29$, Maxsimum value $=95.5$, and Minimum value $=80$.

The method of Jump To Box exercise results are also varied. Before the sample is given treatment, the training method is Jump To Box, first the initial ability test of the front kick. In the pre-test the initial ability of the score from 10 samples in the pre-test with an average $=74.45$, Standard Deviation $=4.06$, 
Maxsimum value $=81$ and Minimum value $=68.5$. Whereas in the post test with an average $=81.95$, Standard Deviation $=4.56$, Maximum Value $=92$, and Minimum value $=76.5$.

Based on the frequency of distribution table of the pretest and post-test front kick ability with the training method Split Squat Jump above, from 10 samples, for the pre-test the value of the kick ability in the category was totally absent $(0 \%)$, good category as many as 5 athletes $(50 \%)$, enough categories as many as 4 athletes (40\%), less categories as many as 1 athlete (10\%), and none in the very poor category. Whereas for the post test the value of the front kick ability is in the excellent category of 7 athletes $(70 \%)$, the good category is 3 people (30\%), and none is in the adequate category, the category is very poor.

Based on the frequency distribution displayed, it is clear that there is an increase in front kick ability by doing the Split Squat Jump exercise. This can be seen in the post-test interval class having increased from the pre-test results. For more details, the frequency distribution of the pre-test and post-test front kick ability above can also be seen in the histogram below:

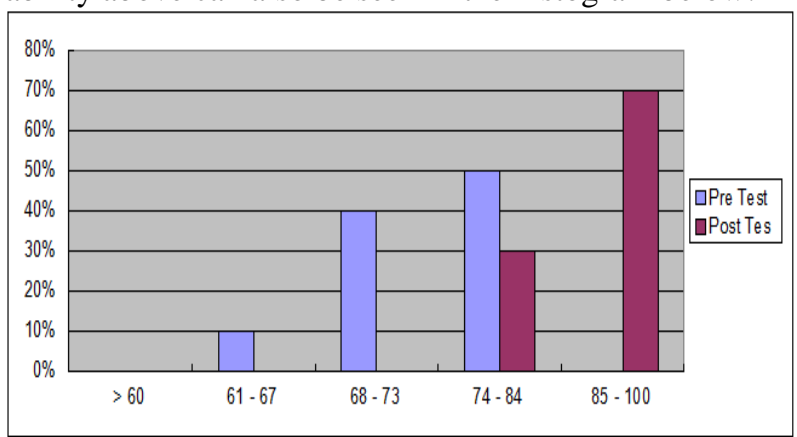

Figure1. Pre-Test and Post-Test Histogram and Front Kick Ability with Method Split Squat Jump Training.

Based on the frequency distribution table above, 10 sample athletes, for pre-test the value of the kick ability in the category of nonexistent $(0 \%)$, good category as many as 5 athletes (50\%), enough categories as many as 5 athletes (50\%), and none of them were in the category of less and very less. Whereas for the post test the value of the front kick ability is in the excellent category as many as 3 athletes (30\%), the good category is 7 athletes $(70 \%)$, and there is no one in the sufficient category, the less category category is lacking.

Based on the frequency distribution displayed, it is clear that there is an increase in the ability of the front kick by doing the Jump To Box exercise. This can be seen in the post test interval class which has increased from the pre test results. For more details, the frequency distribution of the pre-test and post-test front kick capabilitie above can also be seen in the histogram below:

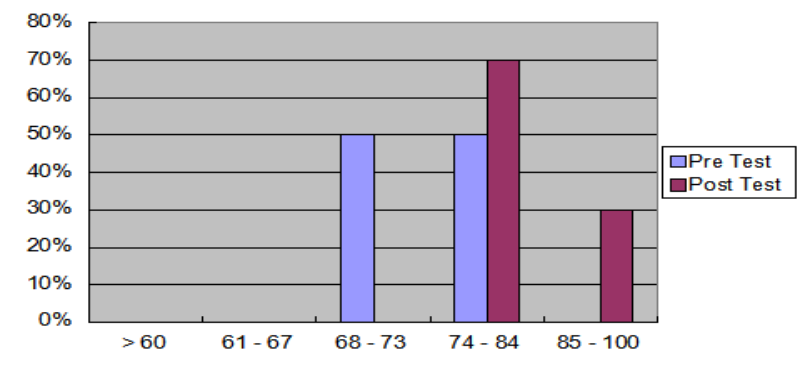

Figure 2. Pre-Test and Post Test Post Test Histrogram Front Kick Ability With Jump To Box training.

The results of the first hypothesis testing based on the results of the calculation of pre-test and post-test data using the statistical approach t-test group training method Split Squat Jump with $\mathrm{t}_{\text {count }} 4.79$ while $\mathrm{t}_{\text {table }}$ 1.833 with a significant level $\alpha=0.05$ and $n=10$. Based on decision making above, then $t_{\text {count }}>$ $t_{\text {table }}(4.79>1.833)$. In other words the proposed research hypothesis is significantly proven.

As has been discussed in the previous study the theory of Split Squat Jump training is a form of exercise that is useful for increasing the ability of explosive power in leg muscles. By applying the Split Squat Jump exercise, Perguruan Silaturahmi Athletes can increase the ability of their front kicks. Giving the Split Squat Jump training had a positive impact on the athlete to improve the ability of the front kick.

In addition, there is a significant effect of the Jump To Box training method on the front kick ability of the Pencak Silat Athletes in Padang. The results of the first hypothesis testing based on the results of the calculation of pre-test and post-test data using the t-test statistical approach group Jump To Box training method with $\mathrm{t}_{\text {count }} 7.73$ while $\mathrm{t}_{\text {table }} 1.833$ with a significant level $\alpha=0.05$ and $n=10$. Based on decision making above, then $t_{\text {count }}>t_{\text {table }}(4.79>1.833)$. In other words the proposed research hypothesis is significantly proven.

Jump To Box Exercise is an exercise that is using the tool, which in this research tool, we choose not proportional to the number of samples. So the sample is not maximal in doing the exercises, so the sample who has done a lot of rest training and at the time of the post test the athlete's ability to produce front kicks in this group did not give a substantial increase.

Based on the hypotheses, the Split Squat Jump training was also better than the jump to box exercise on the front kick ability of the Pencak Silat Athletes in Padang. This hypothesis is seen from the results of the average post test of the Split Squat Jump and Jump To Box exercises showing that there are differences in the results of the mean post test training of Split Squat Jump $=87.05>$ from the average result (post-test) Jump To Box exercise $=81.95(87.08>81.95)$. In this way it can be said that the Split Squat Jump training method is better. 
Based on the explanation and descriptions mentioned previously, then this chapter comprises the analysis and discussion of the findings of this study. The findings of the study will be described in accordance with the objectives of the hypothesis proposed earlier.

\section{CONCLUSION AND SUGGESTION}

Based on the research results and hypothesis testing, it can be concluded that:

1. There is a significant effect on the Split Squat Jump training method ability of the front kick of Pencak Silat athletes in Padang $\mathrm{t}$ count 4.79 while $\mathrm{t}_{\text {table is }} 1.833 \mathrm{t}_{\text {count }}>\mathrm{t}_{\text {table }}(4.79>1.833)$.

2. There is a significant effect of the Jump To Box training method on the ability of the front kick of Pencak Silat athlete in Padang with $t_{\text {count }} 7.73$ while $\mathrm{t}_{\text {table }} 1.833$ then $\mathrm{t}_{\text {count }}>\mathrm{t}_{\text {table }}(4.79>1.833)$.

3. Split Squat Jump training is better than on the Jump To Box training ability of front kick of Pencak Silat athletes in Padang, it can be seen from the average results of the post test Split Squat Jump training $=87.05>$ from the average result (Mean) of Jump to Box training post test $=81.95$. Therefore, it can be said that the Split Squat Jump training method is better.

Based on the conclusions above, the researcher hopes that the Split Squat Jump training can be applied by the trainer as one of the physical training material to improve front kicking ability of the athletes of the Perguruan Silaturahmi Pencak Silat in Padang. In addition, Jump To Box exercises can also be given as one of the training materials for physical conditions to improve the ability of the front kick, by further developing and providing a better variety of training.

\section{REFERENCES}

[1] Arrikunto, Suharsimi. 1989. Metodologi Penelitian. Jakarta : Rineka Cipta.

[2] Arrikunto, Suharsimi. prosedur penelitian suatu pendekatan praktik. Jakarta: Rineka

Cipta.

[3] Ardiansyah, Ahmad. 2017. Pencak Silat The Indonesia Martial Arts, Yogyakarta: Metabook.

[4] David, Pengaruh Latihan Split Squat Jump Terhadap Kecepatan Tendangan Samping (Cechuitui) Atlet Wushu Kodim 0309 Solok, Skripsi. UNP. 2011.

[5] Husaini, Purnomo. (1983). Pengantar Statistika edisi kedua. Jakarta: Bumi Angkasa.

[6] http://www.google.co.id/image/box Jump. Didowloadbtanggal, 15 november 2017.

[7] Johansyah, Hendro. (2014). Pencak Silat Edisi Kedua, Jakarta: Rajagrafindo Persada.

[8] Nurhasan (2001). Latihan Polymetrics. Semarang : IKIP24.
[9] Nossek, (1981). Teori Umum Latihan, Institut Nasional Olahraga, Logos. Jakarta: Pab Dirjen Pendidikan Tinggi.

[10] Radcliffe, Forentinus. (1985). Polymetrics Human Kinetics Publisher. Jakarta: Kantor Menpora.

[11] Rode, James cs. (1985). Latihan Pylometric. Jakarta: Badan Penerbit Universitas Indonesia

[12] Suwirman. (2007). Pencak Silat, Padang: UNP Prees.

[13] Suwirman. 2015. Dasar-dasar Penelitian, Padang: UNP Prees.

[14] Syafrudin. (2011). Ilmu Kepelatihan Olahraga teori dan Aplikasiya Dalam Pembinaan Olahraga, Padang: UNP Prees. 